\title{
Trends in research in which written texts are analyzed in terms of semiotics: Content analysis of graduate thesis within the periods of 1985-2014
}

\author{
Oğuz Kamil Ercantürk ${ }^{1}$
}

\begin{abstract}
This study, which aims to put forward a work of analysis in the field of semiotics, attempted to present graduate thesis works that examined written texts with the method of semiotics within a unity and thus aimed to facilitate access to the different studies that used the semiotic method. Within the scope of the study carried out on the basis of content analysis, 41 graduate thesis works, in which semiotic analysis methods were applied to written texts, were reached. The type and publication year of graduate thesis works, university, institution and department/discipline where the thesis was prepared, language of the published thesis works, population and sampling of theses and the type of written texts in the analyzed works were all determined in the analyzed thesis works by the help of a form used as a data collection tool. The obtained data were presented through frequency tables. It was seen that out of 41 graduate thesis works analyzed within the study, 26 of them were master's thesis, 15 of them were doctoral dissertations, the number of thesis work were gradually increasing at present time, master's thesis works and doctoral dissertations were prepared in 16 and 6 different universities respectively, and the majority of thesis works were prepared at social sciences institute and the department of French language and literature in French language. 48 different textbooks, works, author or poet and 211 texts were selected as the population/group of the study in the sampling graduate thesis works. In addition, it was understood that most of the written texts in these works were chosen from story, novel and fairy tale genres.
\end{abstract}

Keywords: Turkish language teaching; Teaching native language; Semiotics; Linguistics; Textlinguistics

\section{Introduction}

The term semiotics was used to indicate an element produced by the combination of a signified and signifier in the field of linguistics. Indicator, generally outside its own function, comes to mean anything used to signify something for a specific purpose (Başkan, 2003; Barthes, 1979). Everything that establishes communication by evoking that thing and represents another thing even though it

\footnotetext{
${ }^{1}$ Dr., Teacher of Turkish Language and Literature, MEB, okercanturk@gmail.com
} 
Ercantürk, O. K. (2015). Trends in research in which written texts are analyzed in terms of semiotics: Content analysis of graduate thesis within the periods of 1985-2014. International Journal of Human Sciences, 12(2), 1309-1333. doi: $\underline{10.14687 / \text { ijhs.v12i2.3229 }}$

is not that thing itself can be considered as signifier (Parsa \& Parsa, 2012). It is an element which can signify an object, case and entity apart from itself since it carries features that allow itself to replace another thing (Vardar, 2001).

Until Saussure, thinkers, such as Aristotle and Locke, all adopted the view that signifiers reflected the objects in the outside world and accepted the word and its signifiers as valid for everyone, constant and one-dimensional unit (Demir, 2009).

Signifiers were expressed through different concepts by Peirce and Saussure. While Saussure, as noted by Deely (1990), built his approach on a binary model consisting of signifier and signified, Peirce explained signifier in the form of a tripartite model that consisted of interpretant, object and representatum. In these two models that are similar, Peirce's 'representatum' corresponds to Saussure's 'signifier', but Peirce, in contrast to Saussure, divided the signified into two parts as object and interpretant.

Semiotics, whose foundation was laid by Saussure and Peirce by addressing and defining signifier, became an independent branch of science after 1960s. Researchers, such as Louis Hjelmslev, Roland Barthes, Claude Lévi-Strauss, and Algirdas J. Greimas, developed semiotics by carrying out its European tradition that was based on Saussure and, on the other hand, researchers, such as W. Morris, Umberto Eco and Thomas Sebeok, did the same by continuing the American tradition that was based on Peirce.

Semiotics can be defined as a scientific field that analyzes signifying systems such as languages, codes, and signals (Guiraud, 1994) and the subject of semiotics was expressed as everything that is related to the meaning. In this process, thing that semiotics investigates was not what meaning was but rather how it was created. While looking for an answer to this question like expressed by Rifat (1999), semiotics believed whether there was a correlation among units that constitute (a meaningful and constructive whole) a system and set off from the assumption that meaning was born from opposing relationships between elements but not from similar units. In doing so, it does not analyze the surface of the narrative but the production process extending from depths to the surface and does not believe that everything can be said, but believes that everything is in a consistent or inconsistent correlation with each other, and therefore, analytic discourse can be created in a methodological approach that will notice this kind of correlations and will reveal them.

The method, which semiotics use in search of meaning, can find applications in many different disciplines. According to Günay (2012), today developments in sub-units such as literary semiotics, theater semiotics, cinema, advertising, visual, and architecture semiotics that are known as the sub- 
Ercantürk, O. K. (2015). Trends in research in which written texts are analyzed in terms of semiotics: Content analysis of graduate thesis within the periods of 1985-2014. International Journal of Human Sciences, 12(2), 1309-1333. doi: $10.14687 /$ ijhs.v12i2.3229

universe of general semiotics, still continue; for example, cognitive semiotics, music semiotics and even semiotics of passions may be mentioned.

Many different researches can be met when looking at semiotics' relationship with these fields. Graduate thesis works have significant place within these studies. There were also thesis works in which semiotics and linguistics or signs and meaning are associated. Some of these researches can be shown as such: Açan, 2007; Barut, 2010; Çetinkaya, 2006; Demir, 2009; Dervişcemaloğlu, 2005; Er, 2007; Özçelik, 2007; Özdemir, 2010; Vicdan, 2010; Yavuz, 2001.

In addition to this, relationships between semiotics and other fields such as law, cartoons, painting, cinema, visual arts, communication sciences and advertising, space and architecture, were established and graduate thesis works were prepared in relation to these fields. These works can be illustrated as follows: Semiotics and law: (Uzun, 2006); semiotics and cartoons: (Koz, 2007); semiotics and painting: (Akdiş, 2013; Bayav, 2006; Burunsuz, 2007; Sabanc1, 2014); semiotics and cinema: (Buyurgan, 2013; Çelebi, 2009); semiotics and visual arts: (Bulut, 2009; Can, 2011; Denli, 1997; Deveci, 2010; Gün, 1990; Hanc1, 2008; Özmutlu, 2009; Şahin, 2000a; Tekin, 1996; Tomak, 1997; Yllmaz, 2002); semiotics and communication sciences and advertising (Bakan, 2003; Göçmen, 2006; Gür, 2013; Özcan, 2007); semiotics and space and architecture: (Şahin, 2000b).

When articles on the field of semiotics were scanned apart from the graduate thesis works, it was understood that these articles were carried out on similar issues when they were not as comprehensive as graduate thesis works. Some of these articles are on: Semiotics and painting: (Türkcan \& Girmen, 2012; Türkcan, 2013); semiotics and cinema and theater: (Kavuran \& Acar, 2014; Kuleli \& Ural, 2015; Ormanl1, 2014); semiotics and visual arts: (Çulha, 2011; Yıldız, 2005); visual sign: (Aslan Karakul, 2014); consistency of written and visual texts: (Batur, 2010); semiotics and communication sciences and advertising: (Kalaman \& Bat, 2014); semiotics and space and architecture: (Doğan Topçu, 2005; Sayar, 2013).

Fields of Turkish language and Literature also have an important place in the fields where semiotics was selected as the research method. Generally literary texts were selected in this field and they were analyzed in terms of semiotics. In addition these, it was also seen that semiotics was associated with education, education, curriculum, textbooks and texts in textbooks. It was observed that the data from semiotics were intended to be used in the fields of literature and education through these kinds of studies (Ercantürk, 2015).

However, it was noticed during the scanning of all these works that there was no work of analysis related to the studies conducted on semiotics. But, analysis works were seen to become widespread 
Ercantürk, O. K. (2015). Trends in research in which written texts are analyzed in terms of semiotics: Content analysis of graduate thesis within the periods of 1985-2014. International Journal of Human Sciences, 12(2), 1309-1333. doi: $\underline{10.14687 / \text { ijhs.v12i2.3229 }}$

in recent years in Turkey. These analysis works can be exemplified according to their respective fields as follows: Turkish language teaching: (Çoşkun, Özçakmak \& Balc1, 2012; Doğan \& Özçakmak, 2014; Elbir \& Yıldız, 2012; Göçen \& Okur, 2015; Varışoğlu, Şahin \& Göktaş, 2013), Teaching Natural Sciences: (Çalık, Ünal, Çoştu \& Karataş, 2008; Sözbilir \& Kutu, 2008), Teaching Geography: (İncekara, 2009), Teaching Mathematics: (Ulutaş \& Ubuz, 2008), Educational Sciences/Research: (Göktaş, Hasançebi et al., 2012; Karadağ, 2009; Selçuk, Palanc1, Kandemir \& Dündar, 2014), Educational Technology: (Göktaş, Küçük et al., , 2012; Şimşek et al., 2008; Şimşek et al., 2009).

These studies provide guidance for researchers of the related fields. Similarly, an analysis work in the field of semiotics will provide information to the researchers about the studies that were already presented while collecting works in related fields under one roof. An analysis work, which will be carried out on semiotics, will reveal what was already studied and what was not yet studied about the topic and this will guide researchers in their future studies. In addition, an analysis work in this field will also provide the opportunity for researchers to make comparison between studies.

It is necessary to conduct studies that involve in-depth analysis in order for an analysis work on semiotics to carry out this function. This will restrict the comprehensive scope of semiotics and it will also be possible by conducting analysis between studies in same fields and same types.

Keeping these requirements in mind, this study that aims at presenting an analysis work on semiotics is limited by the field of written semiotics and the graduate thesis works that analyzed written texts by semiotic method and were prepared in Turkey.

This analysis work aimed to present graduate thesis works which analyze written texts with semiotic method in unity and thus to facilitate easy access to the different studies in which semiotic method were used. In addition, presenting which written texts were analyzed by semiotic method and providing guidance to the future researchers constitute another purpose of the study. In this regard, the sub-objectives of this study are listed below:

Of the graduate thesis work in which written texts were analyzed by semiotic method;

- How do they range according to thesis type?

- How do they range according to the year of publication?

- How are they distributed according to the universities where they were prepared?

- How are they distributed according to the institute where they were prepared?

- How are they distributed according to the department where they were prepared? 
Ercantürk, O. K. (2015). Trends in research in which written texts are analyzed in terms of semiotics: Content analysis of graduate thesis within the periods of 1985-2014. International Journal of Human Sciences, 12(2), 1309-1333. doi: $\underline{10.14687 / \text { ijhs.v12i2.3229 }}$

- How do they range according to the language of publication?

- How do they range according to the population of the research?

- How do they range according to the sampling of the research?

- How do they range according to the types of the analyzed written texts?

In line with these objectives and sub-objectives, written texts taken from 41 graduate thesis works, accessed from YOK National Thesis Center and Central Library of Istanbul University, were analyzed by semiotic method.

\section{Methodology}

Aiming to present an analysis work in the field of semiotics and analyzing written texts taken from graduate thesis works with this aim by semiotic method, this study was carried out on the basis of content analysis. Cohen, Manion \& Morrison (2007) stated that content analysis was a method used in organizing, classifying, comparing texts and deducing theoretical results from them.

The reason behind in the preference of content analysis in this study can be explained by analyzing the documents related the topic of study in details and bringing similar data together through the specified criteria.

\subsection{Population/Sampling}

The population of the study consisted of researches in which written texts were analyzed by semiotic method.

Semiotic analysis method involves reading. But, here reading is different from common reading because commong reading is mostly interested in surface meaning. According to Rifat'a (2011), the acquisition of reading in the sense of semiotic analysis requires more intense, more careful, more sensitive and more theoretical effort: Semiotic analysis (structure-disarrangement and structure reestablishment) is an act of re-establishing and re-structuring by extricating and disarranging the structure whose existence was accepted. In the acquisition of reading in this sense, each original text and each originally meaningful system for semiotician will also be source of scientific invention in terms of theoretical model.

Reader in semiotic reading is in pursuit of meaning behind the obvious not on the surface of the text. According to Demir (2009), semiotics that aims at analyzing a meaningful whole adopted a hypothetical and deductive method and developed a theory of signification. Semiotics aims at presenting a meaningful whole through a metalanguage if it consisted of which significant semantic layers. 
Ercantürk, O. K. (2015). Trends in research in which written texts are analyzed in terms of semiotics: Content analysis of graduate thesis within the periods of 1985-2014. International Journal of Human Sciences, 12(2), 1309-1333. doi: $\underline{10.14687 / \text { ijhs.v12i2.3229 }}$

In semiotic analysis, how well whatever intended to say in the text was said is more important than who said it. Therefore, semiotics explores the process of meaning production in text. In this process, semiotics starts from the idea that meaning arises from differences and contrasts like in structuralism.

In the process of achieving meaning by setting out from contrasts, it is necessary, according to İnceoğlu \& Çomak (2009), to analyze the text, whatever kind it may be (news, interviews, columns, headlines, symbol, advertisement, poster, stories, films, poetry, novel), by descending from the most superficial to the deepest plane.

Both realizing things implied by this text (universe of meanings) and comprehending and restructuring the format as well as the order (format of the content) of whatever said in them are attempted when analyzing a text. In other words, semiotic analysis leaves the features of expressional plane, i.e. linguistic and formal structures, at another place of event when approaching a meaningful whole (text) and directly heads towards the format of content plane (Rifat, 1996; Rifat, 2011).

The population of the study, selected for this research, adopted this approach of semiotics and it consists of research that analyzed written texts by setting off from this approach. Research that discussed written texts only in terms of signs (signifier-signified) in texts or research that analyzed written texts semantic or textual linguistic points of views were not included in the population of the study.

The sampling of the study was created by selecting graduate thesis works prepared at universities in Turkey from the population of the study where written texts were analyzed through semiotic method.

In this context, graduate thesis works at YOK National Thesis Center that are included in the scope of the study were accessed at first. Thesis works that were included in the sampling and those that were given access at YOK National Thesis Center were collected. Thesis works that were included within the scope of the study, but were not granted access at YOK National Thesis Center were provided access at the Central Library of Istanbul University.

Thus, 41 graduate thesis works in which semiotic analysis method was applied to written texts had been accessed in order to be analyzed within the scope of the study. 
Ercantürk, O. K. (2015). Trends in research in which written texts are analyzed in terms of semiotics: Content analysis of graduate thesis within the periods of 1985-2014. International Journal of Human Sciences, 12(2), 1309-1333. doi: $\underline{10.14687 / \text { ijhs.v12i2.3229 }}$

\subsection{Data Collection Tool}

A form, developed by the researcher as the data collection tool, was used in the study. Types and publication year of graduate thesis works, university, institution, department/discipline where thesis works were prepared, language of publication in thesis works, population and sampling and types of analyzed written texts were included in the created form. The finishing touches were given to the form with the help of domain experts and data on graduate thesis works analyzed within the scope of the research were collected in accordance with these headings.

\subsection{Data Analysis}

A template was created by inserting the headings in the data collection form in MS Excel program in order to collect data within the scope of the research. The data obtained from graduate thesis works within the scope of the research were filled with this template. Data, analyzed by descriptive content analysis were presented in tables.

\section{Findings}

In this section, data obtained within the scope of the research will be presented according to the titles included in data collection form that was prepared with the sub-objectives of the research.

The data obtained under this section, research, data collection will be presented according to the headings in the form prepared in accordance with sub-research purposes.

\subsection{Findings Regarding the Types of Graduate Thesis Works within the Scope of the} Research

Graduate thesis works, included in the sampling of the research, were divided into two as master's thesis works and doctoral dissertations. The distribution of graduate thesis works, included in the sampling according to their types, can be shown as follows:

Table 1: Distribution of Graduate Thesis Works Analyzed within the Scope of Research According to Their Types

\begin{tabular}{lr}
\hline Graduate Thesis Type & Frequency \\
\hline Master's & 26 \\
\hline Doctoral & 15 \\
\hline Total & 41 \\
\hline
\end{tabular}

It was seen when analyzing the distribution of graduate thesis works analyzed within the scope of the research according to their types that out of 41 graduate thesis works, 26 of them were master's theses and 15 of them were doctoral dissertations. According to this, it is possible to state that most 
Ercantürk, O. K. (2015). Trends in research in which written texts are analyzed in terms of semiotics: Content analysis of graduate thesis within the periods of 1985-2014. International Journal of Human Sciences, 12(2), 1309-1333. doi: $\underline{10.14687 / \text { ijhs.v12i2.3229 }}$

of graduate thesis works that analyze written texts according to semiotic analysis method consisted of master's thesis works.

Selecting a text or a work generally for the application of semiotic analysis method to the written texts and inadequacy of these for preparing a dissertation at doctoral level can be considered as a reason for this.

Preparing a dissertation doctoral level in which more than one written text or works are analyzed in terms of semiotics will provide more detailed information to researchers related to the owner, author, poet of the texts or textbooks.

\subsection{Distribution of Graduate Thesis Work within the Scope of Research According to Publication Year}

Graduate thesis works, in which written texts were analyzed through semiotic methods, were prepared at different periods from the past till the present.

Table 2: Distribution of Graduate Thesis Work within the Scope of Research According to Publication Year

\begin{tabular}{|c|c|c|c|}
\hline \multirow[b]{2}{*}{ Publication Year } & \multicolumn{2}{|c|}{ Frequency } & \multirow[b]{2}{*}{ Total } \\
\hline & Master's & Doctoral & \\
\hline 1985 & 1 & & 1 \\
\hline 1986 & 1 & & 1 \\
\hline 1990 & 1 & & 1 \\
\hline 1991 & 1 & & 1 \\
\hline 1993 & 1 & 1 & 2 \\
\hline 1995 & 1 & & 1 \\
\hline 1996 & 1 & & 1 \\
\hline 1997 & & 1 & 1 \\
\hline 1999 & & 3 & 3 \\
\hline 2001 & 1 & & 1 \\
\hline 2002 & 1 & 1 & 2 \\
\hline 2004 & 3 & & 3 \\
\hline 2005 & 3 & & 3 \\
\hline 2006 & 1 & & 1 \\
\hline 2007 & 1 & 1 & 2 \\
\hline 2008 & 1 & 2 & 3 \\
\hline 2009 & & 1 & 1 \\
\hline 2010 & 2 & & 2 \\
\hline 2011 & 2 & 2 & 4 \\
\hline 2012 & 1 & 1 & 2 \\
\hline 2013 & 2 & 2 & 4 \\
\hline 2014 & 1 & & 1 \\
\hline Total & 26 & 15 & 41 \\
\hline
\end{tabular}

It was seen when looking at the acceptance dates of the graduate thesis works prepared with the aim of analyzing written texts through semiotic method within the scope of the research that they 
Ercantürk, O. K. (2015). Trends in research in which written texts are analyzed in terms of semiotics: Content analysis of graduate thesis within the periods of 1985-2014. International Journal of Human Sciences, 12(2), 1309-1333. doi: $\underline{10.14687 / \text { ijhs.v12i2.3229 }}$

began in 1985. Of the graduate thesis works prepared on the field, it can be noticed that the number of works, which was 1 in 1995, reached 2 in 1993, 3 after 1999 and 4 in 2011. In this sense, it is safe to state that the number of graduate thesis works, prepared with the aim of analyzing written texts through semiotic perspective, increased from the past to the present.

While one of the reasons behind the increase in this number can be stated as the recognition of semiotics, one of the other reasons is that doctoral dissertations have been prepared in the related field. In addition, it can be stated when looking at the distribution of graduate thesis works included in the sampling according to years that thesis works at master's level were prepared more than those at doctoral level. It can be declared that the preparation stage of doctoral dissertations that take long time might have an effect on this.

It can be mentioned when looking at the distribution of graduate thesis works within the scope of the research according to thesis types that doctoral dissertations began in 1993 in this field even though master's thesis works started in 1985. The reason behind this might be that doctoral dissertations in the early years focused on how to perform written text analysis through semiotic method instead of analyzing them.

\subsection{Distribution of Graduate Thesis Works within the Scope of Research According to the Universities they were prepared at}

The distribution of graduate thesis works that were included within the sampling and analyze written texts through semiotic analysis method according to the universities they were prepared can be seen as follows:

Table 3: Distribution of Graduate Thesis Works within the Scope of Research According to the Universities they were prepared

\begin{tabular}{lccr}
\hline & \multicolumn{2}{c}{ Frequency } & Total \\
\cline { 2 - 4 } University & Master's Thesis & Doctoral Dissertation & 1 \\
\hline Afyon Kocatepe University & 1 & 1 & 2 \\
\hline Anadolu University & 1 & 1 & 1 \\
\hline Ankara University & & 3 & 7 \\
\hline Atatürk University & 4 & & 1 \\
\hline Bosphorus University & 1 & & 1 \\
\hline Cumhuriyet University & 1 & & 1 \\
\hline Çanakkale Onsekiz Mart & 1 & & 1 \\
University & & & 2 \\
\hline Çukurova University & 1 & & 1 \\
\hline Ege University & & & 1 \\
\hline Erciyes University & 1 & 1 \\
\hline Frrat University & 1 & & \\
\hline Galatasaray University & 1 & & \\
\hline Gazi University & 1 & & \\
\hline
\end{tabular}


Ercantürk, O. K. (2015). Trends in research in which written texts are analyzed in terms of semiotics: Content analysis of graduate thesis within the periods of 1985-2014. International Journal of Human Sciences, 12(2), 1309-1333. doi: $\underline{10.14687 / \text { ijhs.v12i2.3229 }}$

\begin{tabular}{lcrr}
\hline Hacettepe University & 2 & 4 & 6 \\
\hline İstanbul University & 7 & 4 & 11 \\
\hline Marmara University & 1 & & 1 \\
\hline Selçuk University & 1 & & 1 \\
\hline Uludă̆ University & 1 & 15 & 1 \\
\hline Total & 26 & 41 \\
\hline
\end{tabular}

18 different universities can be noticed when looking at the distribution of graduate thesis works that were included in the sampling and in which written texts were analyzed through semiotic method according to the universities they were prepared. This amount can be said to be inadequate when considering the number of universities in Turkey. While master's theses in the sampling were seen to be prepared in 16 different universities, doctoral dissertations were conducted in 6 different universities. It can be stated that the availability of experts on the field of semiotics who were employed at universities might have a share in this distribution.

It can be noticed when examining the distribution of graduate thesis works, included within the scope of the research, according to the universities they were prepared that Istanbul University is the institution in which thesis works on the related field were prepared the most in terms of number. It was followed by Atatürk University and Hacettepe University was secured $3^{\text {rd }}$ place in the ranking of universities in which graduate thesis works on the related field were prepared.

While Istanbul University was the institution in which master's theses were prepared the most in terms of number within the scope of the research, Hacettepe University and Istanbul University were seen to be the two institutions in which doctoral dissertations were conducted the most in number.

\subsection{Distribution of Graduate Thesis Works within the Scope of Research According to the}

\section{Institutions they were prepared}

Graduate thesis works, included in the sampling, were prepared at different universities and university institutes. The distribution of graduate thesis works within the scope of the research according to the institutes in which they were prepared can be seen as follows:

Table 4: Distribution of Graduate Thesis Works within the Scope of Research According to the Institutes they were prepared

\begin{tabular}{lccrr}
\hline & \multicolumn{2}{c}{ Frequency } & Total \\
\cline { 2 - 4 } Institute & Master's Thesis & Doctoral Dissertation & 2 \\
\hline Institute of Educational Sciences & 2 & 15 & 39 \\
\hline Social Sciences Institute & 24 & 15 & 41 \\
\hline Total & 26 & & \\
\hline
\end{tabular}

Out of 41 graduate thesis works analyzed within the scope of the study, 39 of them were seen to be prepared at Social Sciences Institute and 2 of them were conducted at Institute of Educational 
Ercantürk, O. K. (2015). Trends in research in which written texts are analyzed in terms of semiotics: Content analysis of graduate thesis within the periods of 1985-2014. International Journal of Human Sciences, 12(2), 1309-1333. doi: $10.14687 /$ ijhs.v12i2.3229

Sciences. It is an expected result to discover that thesis works on semiotics are administered mostly at Social Sciences Institutes since semiotics is included in the field of social sciences. However, thesis works that will be conducted at Institutes of Educational Sciences will contribute to the use of semiotic data in the field of education.

\subsection{Distribution of Graduate Thesis Works within the Scope of Research According to the Department /Discipline they were prepared}

Graduate thesis works, included in the sampling, were prepared at different departments and disciplines. The distribution of graduate thesis works within the scope of the research according to the departments/disciplines in which they were prepared can be seen as follows:

Table 5: Distribution of Graduate Thesis Works Analyzed within the Scope of Research According to the Departments/Disciplines they were prepared

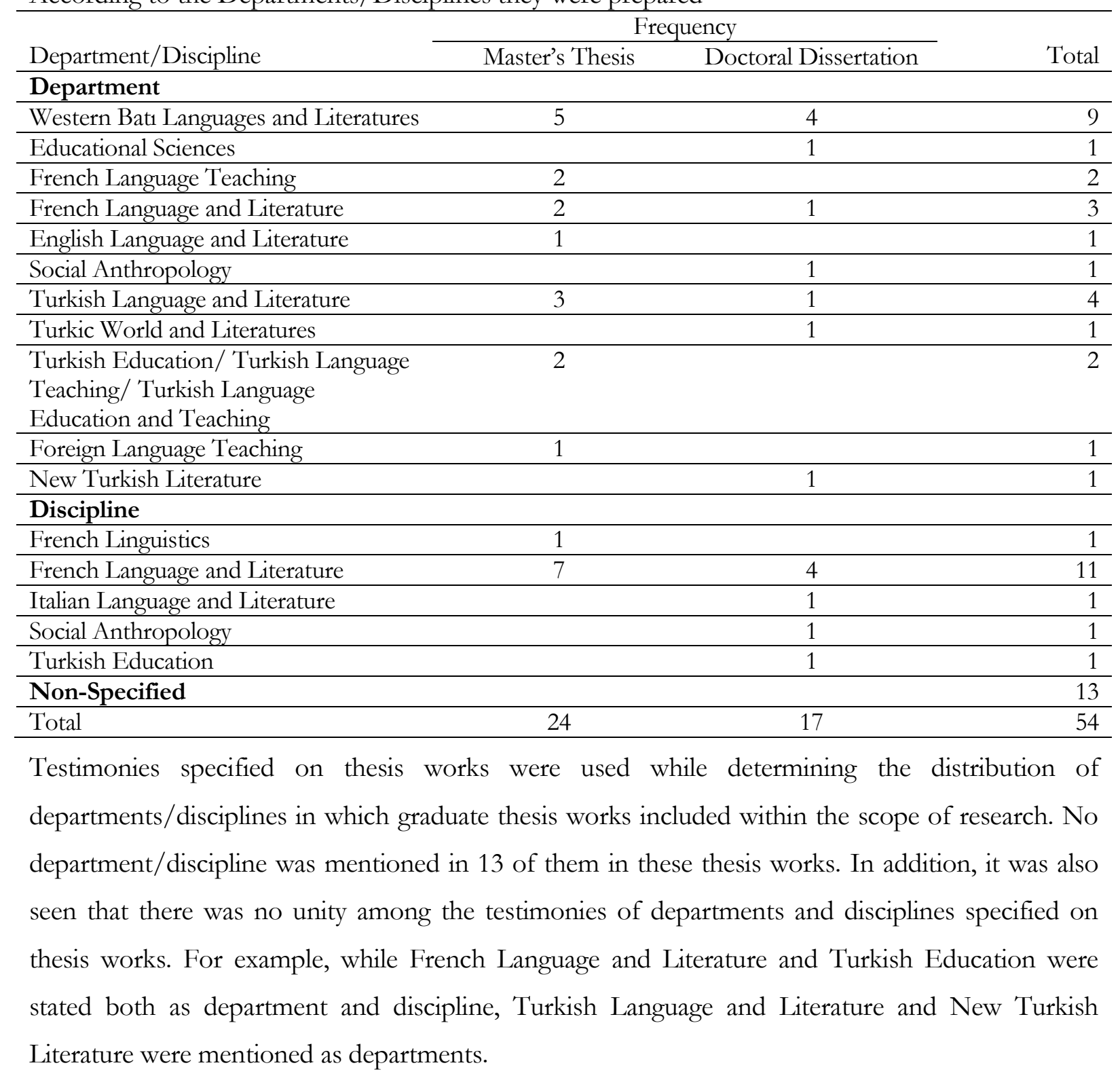


Ercantürk, O. K. (2015). Trends in research in which written texts are analyzed in terms of semiotics: Content analysis of graduate thesis within the periods of 1985-2014. International Journal of Human Sciences, 12(2), 1309-1333. doi: $\underline{10.14687 / \text { ijhs.v12i2.3229 }}$

It was noticed when examining the distribution of graduate thesis works, included in the sampling, according to department in which they were conducted that these thesis works were prepared at the departments of Western Languages and Literatures, Turkish Language and Literature and French Language and Literature respectively. It was also seen while examining the distribution of graduate thesis works in the sampling according to the disciplines in which they were prepared that the discipline of French Language and Literature secured the first place. In this regard, French Language and Literature can be said to be the department/discipline in which most number of graduate thesis works were prepared on the analysis of written texts in terms of semiotics. This is applicable for thesis works in both master's and doctoral levels.

\subsection{Distribution of Graduate Thesis Works within the Scope of Research According to the}

\section{Language of Publication}

The distribution of graduate thesis works analyzed within the scope of the research according to the language of publication can be shown as follows:

Table 6: Distribution of Graduate Thesis Works within the Scope of Research According to the Language of Publication

\begin{tabular}{lccr}
\hline \multirow{2}{*}{ Publication Language } & \multicolumn{2}{c}{ Frequency } & Total \\
\cline { 2 - 4 } French & Master's Thesis & Doctoral Dissertation & 21 \\
\hline Italian & 14 & 7 & 1 \\
\hline Turkish & 12 & 1 & 19 \\
\hline Total & 26 & 7 & 41 \\
\hline
\end{tabular}

Three different languages, French, Turkish and Italian, can be seen when examining the publication language of the graduate thesis works included in the sampling. French became the most preferred language in the composition of thesis work in the related field. It was followed by Turkish and Italian languages.

Graduate thesis works in the scope of the research were mostly prepared in French language because they were carried out more in departments/disciplines of Western Languages and Literatures and French Language and Literature.

3.7 Distribution of Graduate Thesis Works in the Scope of Research According to the Target Population/Group

Different target population/group was determined with the aim of analyzing the written texts in graduate thesis works within the scope of the research through semiotic method. Distribution of graduate thesis works in the sampling according to target population/group can be shown as follows: 
Ercantürk, O. K. (2015). Trends in research in which written texts are analyzed in terms of semiotics: Content analysis of graduate thesis within the periods of 1985-2014. International Journal of Human Sciences, 12(2), 1309-1333. doi: $\underline{10.14687 / \text { ijhs.v12i2.3229 }}$

Table 7: Distribution of Graduate Thesis Works Analyzed in the Scope of Research According to the Target Population/Group

Textbook/Work/Author/Poet Frequency

$6^{\text {th }}$ Grade Turkish language textbook (Koza, 2009-2010)

$6^{\text {th }}$ Grade Turkish language textbook (MEB, 2001)

$6^{\text {th }}$ Grade Turkish language textbook (MEB, 2009-2010)

$7^{\text {th }}$ Grade Turkish language textbook (MEB, 2006)

$8^{\text {th }}$ Grade Turkish language textbook (Akçağ, 2000-2001)

$8^{\text {th }}$ Grade Turkish language textbook (Dörtel, 2000-2001)

$8^{\text {th }}$ Grade Turkish language textbook (Düzgün, 2000-2001)

$8^{\text {th }}$ Grade Turkish language textbook (Mahir, 2000-2001)

$8^{\text {th }}$ Grade Turkish language textbook (MEB, 2000-2001)

$8^{\text {th }}$ Grade Turkish language textbook (MEB, 2006)

$8^{\text {th }}$ Grade Turkish language textbook (Metinler, 2000-2001)

Ahmet Hamdi Tanpinar

Alain-Fournier

Albert Camus

Alphonse Mudet

Emile Zola

Eric Emmanuel Schimitt

Frederic, Louis Sauser (Blaise Cendrars)

Travel Notebooks

Travel Literature

Gilbert Adair

Grimm Brothers

Guy de Maupassant

Haldun Taner

Halit Ziya Ușaklıgil

J. M. G. Le Clezio

Jean Cocteau

Jean Giraudoux

Marc-Antoine Mathieu

Marcel Ayme

Marchesa Colombi

Marguerite Yourcenar

Marquerite Duras

Mathias Enard

Michel Tournier

Murathan Mungan

Neera

Oğuz Atay

Ömer Seyfettin

Pertev Naili Boratav

Raymond Radiguet

Reşat Nuri Güntekin

Sabahattin Ali

Selçuk Baran

Sibilla Aleramo

Simone de Beauvoir

Şeyh Gâlib

Tourist Guides

Total (48 Textbooks/Work/Author/Poet) 
Ercantürk, O. K. (2015). Trends in research in which written texts are analyzed in terms of semiotics: Content analysis of graduate thesis within the periods of 1985-2014. International Journal of Human Sciences, 12(2), 1309-1333. doi: $\underline{10.14687 / \text { ijhs.v12i2.3229 }}$

It was realized when looking at the target population of the graduate thesis works analyzed within the scope of the research that a literary work/text by a single author was generally analyzed in terms of semiotics. In addition to this, there were also thesis works in which literary works by more than one author or more than one literary work/text by a single author were analyzed. The above-table, which reflects the distribution of graduate thesis works analyzed within the scope of the research according to target population/group, shows how many different works those names in the target population were chosen.

It was noticed when examining the distribution of graduate thesis works, analyzed within the scope of the research, according to target population/ group that 48 different textbooks, works, authors or poets were selected as target population/group for analyzing the written texts in those thesis works. Frequencies, which specified this in the above table, indicate that how many different works textbooks, works, authors or poets were selected for.

In this context, it was discovered when looking at the target population/group in graduate thesis works in the sampling that they mostly included authors of literary texts/works. In this sense, J. M. G. Le Clezio and Michel Tournier were the most preferred authors whose texts were selected for analysis. In addition to them, Ahmet Hamdi Tanpinar, Guy de Maupassant, Marcel Ayme, Murathan Mungan and Pertev Naili Boratav were also authors whose texts were chosen for analysis.

\subsection{Distribution of Graduate Thesis Works within the Scope of Research According to}

\section{Sampling Texts}

Different written texts were selected in graduate thesis works within the scope of the research, in order to analyze them through semiotic method. The distribution of these texts can be shown as follows:

Table 8: Distribution of Graduate Thesis Works Analyzed within the Scope of Research According to Sampling Texts

\begin{tabular}{|c|c|c|}
\hline Textbook/Work/Author/Poet & Title of the Text & $\begin{array}{c}\text { Number of } \\
\text { Text }\end{array}$ \\
\hline $\begin{array}{l}6^{\text {th }} \text { Grade Turkish language } \\
\text { textbook (Koza, 2009-2010) }\end{array}$ & $\begin{array}{l}\text { Eskici, Süpermen İstanbul'a Düştü, Çocuk ile Geyik, Prensi } \\
\text { Olmayan Masal Kitabı }\end{array}$ & 4 \\
\hline $\begin{array}{l}6^{\text {th }} \text { Grade Turkish language } \\
\text { textbook (MEB, 2001) }\end{array}$ & Küfeci & 1 \\
\hline $\begin{array}{l}6^{\text {th }} \text { Grade Turkish language } \\
\text { textbook (MEB, 2009-2010) }\end{array}$ & $\begin{array}{l}\text { Çocuk Kitapliğında Sabah Tartışmas1, Kitap Kuşum } \\
\text { Uçuverdi, Ömür Boyu Mutluluk, İstanbul Liseli Küçük } \\
\text { Hasan, Eskici }\end{array}$ & 5 \\
\hline $\begin{array}{l}7^{\text {th }} \text { Grade Turkish language } \\
\text { textbook (MEB, 2006) }\end{array}$ & Arkadaşım, Mustafa Kemal'in Askerleri, Haşmet Gülkokan & 3 \\
\hline $8^{\text {th }}$ Grade Turkish language & Yüz Ak1, Oh Be!, Zorlara Dağ Dayanmaz, Koşma & 4 \\
\hline
\end{tabular}


Ercantürk, O. K. (2015). Trends in research in which written texts are analyzed in terms of semiotics: Content analysis of graduate thesis within the periods of 1985-2014. International Journal of Human Sciences, 12(2), 1309-1333. doi: $\underline{10.14687 / \text { ijhs.v12i2.3229 }}$

textbook (Akçă̆, 2000-2001)

$8^{\text {th }}$ Grade Turkish language İstiklâl Marşı, Kızımı Da Götür, Karga İle Tilki, Derslerine

6 textbook (Dörtel, 2000-2001) Çalışacaklarmış, Canım İstanbul, Alışkanlık

$8^{\text {th }}$ Grade Turkish language Ergenekon Destanı, Sarımsak, Cimrinin Ziyafeti, Fatih 4 textbook (Düzgün, 2000-2001) Sultan Mehmet

$8^{\text {th }}$ Grade Turkish language Yalnızlaşan ve Makineleşen İnsan, Karanfiller ve Domates textbook (Mahir, 2000-2001)

Suyu, Milli Eğitim, Sorumluluk, Dil Bilmek, İnsan Sevgisi ve Evrensellik, Dönüş

$8^{\text {th }}$ Grade Turkish language Onuncu Y1l Nutku, Öğretmene Sayg1, Şöyle Falan Olmak, textbook (MEB, 2000-2001) Atasözü-Özdeyiş, Atatürk Diyor Ki, Nasrettin Hoca, Eğer Gençlik Bilseydi, Küçük Ağa, Bilgisayarın Yetenekleri, Başka Karadeniz Yok

$8^{\text {th }}$ Grade Turkish language İhtiyar Çilingir, Tanıdığım Çocuklardan Rüstem, Küfe, Kuş textbook (MEB, 2006) Yemi, Son Kuşlar

$8^{\text {th }}$ Grade Turkish language İstanbul'u Dinliyorum, Kültürlü İnsanlar Yetiştirmek, 5 textbook (Metinler, 2000-2001)

Ahmet Hamdi Tanpinar

Ömer'den Serdar'a Mektup

Huzur, Yaz Yağmuru, Teslim, Acıbademdeki Köşk, Rüyalar,

Ademle Havva, Bir Tren Yolculuğu, Yaz Gecesi, Abdullah

Efendinin Rüyaları, Geçmiş Zaman Elbiseleri, Bir Yol,

Erzurumlu Tahsin, Evin Sahibi, Fal,

\begin{tabular}{|c|c|c|}
\hline Alain-Fournier & Le Grand Meaulnes (Koca Meaulnes) & 1 \\
\hline Albert Camus & L'etranger (Yabanc1) & 1 \\
\hline Alphonse Mudet & La Chevre de M. Seguin (M. Seguin'in Keçisi) & 1 \\
\hline Emile Zola & Meyhaneci & 1 \\
\hline Eric Emmanuel Schimitt & L'enfant de Noe (Nuh'un Çocukları) & 1 \\
\hline $\begin{array}{l}\text { Frederic, Louis Sauser (Blaise } \\
\text { Cendrars) }\end{array}$ & L'or & 1 \\
\hline Travel Books & $\begin{array}{l}\text { Istanbul Carnets d'Orient, Istanbul Carnet de la Sublime } \\
\text { Porte, Istanbul et les Stambouliotes }\end{array}$ & 3 \\
\hline Travel Literature & Le Génie du Lieu, Istanbul & 2 \\
\hline Gilbert Adair & Kulenin Anahtar1 & 1 \\
\hline Grimm Brothers & $\begin{array}{l}\text { Bremen Mızıkacıları, Pamuk Prenses, Kırmızı Başlıklı Kız, } \\
\text { Kül Kedisi, Rapunzel }\end{array}$ & 5 \\
\hline Guy de Maupassant & La Parure, Madame Baptiste, La Ficelle & 3 \\
\hline Haldun Taner & $\begin{array}{l}\text { Günün Adamı, Dişardakiler, ...Ve Değirmen Dönerdi, } \\
\text { Fazilet Eczanesi, Huzur Çıkmazı }\end{array}$ & 5 \\
\hline Halit Ziya Uşaklıgil & Mai ve Siyah & 1 \\
\hline J. M. G. Le Clezio & $\begin{array}{l}\text { Lullaby, La saison des pluies (Yağmur Mevsimi), Göçmen } \\
\text { Yıldız }\end{array}$ & 3 \\
\hline Jean Cocteau & Thomas l'imposteur (Sahtekar Thomas) & 1 \\
\hline Jean Giraudoux & Siegfried & 1 \\
\hline Marc-Antoine Mathieu & Le Dessin (Resim) & 1 \\
\hline Marcel Ayme & Le Passe-Muraille (Duvargeçen), Des Bottes de Sept Lieues & 2 \\
\hline Marchesa Colombi & Un Matrimonio in Provincia & 1 \\
\hline Marguerite Yourcenar & L'Oeuvre Au Noir (Zenon) & 1 \\
\hline Marquerite Duras & La Vie Tranquille & 1 \\
\hline Mathias Enard & $\begin{array}{l}\text { Parle-Leur De Batailles, De Rois Et D'éléphants (Savaşları, } \\
\text { Kralları ve Filleri Anlat Onlara) }\end{array}$ & 1 \\
\hline Michel Tournier & $\begin{array}{l}\text { Les Suaires De Veronique, Le Coq de Bruyere (Çalı } \\
\text { Horozu), La jeune fille et la mort (Genç Kız ve Ölüm) }\end{array}$ & 3 \\
\hline Murathan Mungan & $\begin{array}{l}\text { Çarpışma, Dört Kişilik Bahçe, Ç.C., Şahmeranın Bacakları, } \\
\text { Ökkeş ile Cengaver, Kasım ile Nâsır, Binalî ile Temir, Ensar } \\
\text { ile Civan, Yılan ve Geyiğe Dair, Yedi Cücesi Olmayan Bir }\end{array}$ & 18 \\
\hline
\end{tabular}


Ercantürk, O. K. (2015). Trends in research in which written texts are analyzed in terms of semiotics: Content analysis of graduate thesis within the periods of 1985-2014. International Journal of Human Sciences, 12(2), 1309-1333. doi: $\underline{10.14687 / \text { ijhs.v12i2.3229 }}$

\begin{tabular}{|c|c|c|}
\hline & $\begin{array}{l}\text { Pamuk Prenses, Stelyanos Hrisopulos Gemisi, Zamanımızın } \\
\text { Bir Külkedisi, Yüzyıllık Uyuyan Güzel, Aşkın Gözyaşları ya } \\
\text { da Rapunzel ile Avare, Murathan ile Selvihan ya da Bir Billur } \\
\text { Köşk Masalı, Âzer ile Yadigâr, Ulak ile Sadrazam, Suret } \\
\text { Masalı }\end{array}$ & \\
\hline Neera & Teresa & 1 \\
\hline Oğuz Atay & Unutulan & 1 \\
\hline Ömer Seyfettin & $\begin{array}{l}\text { Hikâye tasnifi: 1- Toplumsal-Mîzâhî Hikâyeler 2- Eski } \\
\text { Kahramanlar 3- Yeni Kahramanlar 4- Efrûz Bey Serisi 5- } \\
\text { Câbî Efendi Serisi 6- ÇıcuMuk Hatıraları 7- Tarihî ve Vatanî } \\
\text { Hikâyeler 8- Zamane Yiğitleri 9- Fantazi Hikâyeler 10- Yeni } \\
\text { Lisanla Hikâyeler 11- Bir Masal }\end{array}$ & 66 \\
\hline Pertev Naili Boratav & $\begin{array}{l}\text { Dünya Güzeli, Bacı Bacı Can Bacı, Hüsnü Yusuf Şehzade, } \\
\text { Yatalak Mehmet }\end{array}$ & 4 \\
\hline Raymond Radiguet & Le Diable Au Corps (İçimizdeki Şeytan) & 1 \\
\hline Reşat Nuri Güntekin & Porselen Çay İbriği & 1 \\
\hline Sabahattin Ali & Hasan Boğuldu & 1 \\
\hline Selçuk Baran & Bir Solgun Adam, Bozkır Çiçekleri, Güz Gelmeden & 3 \\
\hline Sibilla Aleramo & Una donna & 1 \\
\hline Simone de Beauvoir & $\begin{array}{l}\text { Mémoires D’une Jeune Fille Rangée, La Force De L'âge (I- } \\
\text { II), La Force Des Choses (I-II) }\end{array}$ & 3 \\
\hline Şeyh Gâlib & Hüsn ü Aşk & 1 \\
\hline Tourist Guides & $\begin{array}{l}\text { Istanbul le Guide Voir, Istanbul le Guide Évasion, Istanbul } \\
\text { le Guide du Routard }\end{array}$ & 3 \\
\hline Total & & 211 \\
\hline
\end{tabular}

A total of 211 texts/works were analyzed when looking at the texts/works studied in graduate thesis works within the scope of the research. In this regard, while texts/works of Ömer Seyfettin were analyzed the most, those of Murathan Mungan were the second and texts/works of Ahmet Hamdi Tanpinar were analyzed the third.

\subsection{Distribution of Graduate Thesis Works within the Scope of Research According to} Analyzed Text Type

The texts, selected for conducting analysis through semiotic method in graduate thesis works included within the scope of the research, were seen to be in different types. Distribution of written texts analyzed in graduate thesis works according to their types can be shown as follows:

Table 9: Distribution of Graduate Thesis Works within the Scope of Research According to Analyzed Text Type

\begin{tabular}{lr}
\hline Text Type & Frequency \\
\hline Memoir & 2 \\
\hline Proverb & 1 \\
\hline Comic Book & 1 \\
\hline Essay & 3 \\
\hline Compilation & 1 \\
\hline Epic & 1 \\
\hline Criticism & 1 \\
\hline
\end{tabular}


Ercantürk, O. K. (2015). Trends in research in which written texts are analyzed in terms of semiotics: Content analysis of graduate thesis within the periods of 1985-2014. International Journal of Human Sciences, 12(2), 1309-1333. doi: $\underline{10.14687 / \text { ijhs.v12i2.3229 }}$

\begin{tabular}{lr}
\hline Anecdotes & 1 \\
\hline Travel & 9 \\
\hline News & 1 \\
\hline Conference & 1 \\
\hline Article & 4 \\
\hline Tales & 10 \\
\hline Letter & 1 \\
\hline Mathnawi & 1 \\
\hline Oration & 2 \\
\hline Play & 7 \\
\hline Stories & 134 \\
\hline Novel & 19 \\
\hline Interview & 1 \\
\hline Conversation & 2 \\
\hline Poem & 4 \\
\hline Biography & 4 \\
\hline Total & 211 \\
\hline
\end{tabular}

211 written texts/works were analyzed in graduate thesis works discussed within the scope of the research through semiotic method. Stories were noticed to be the most preferred text type for conducting analysis when looking at what type of texts these written texts/works had been. Novels secured the second place and tales got the third place for performing analysis in graduate thesis works within the scope of the research.

In this context, event-based text types were seen to be preferred in graduate thesis works analyzed within the scope of the research for conducting analysis through semiotic method. The reason behind this can be that the discovery of the text production process and obtaining a deeper understanding of the text are said to be quite easier in event-based texts

\section{Results and Discussion}

Meaning is a phenomenon which proves to be difficult for people in the stages of recognition and interpretation and becomes an issue for subjective assessments during its interpretation. It is necessary to apply different text reading and analysis methods in order to assess meaning scientifically and objectively. One of these methods is semiotic method.

It is possible to come across to studies in literature that were prepared by using semiotic analysis method. In these studies, it is probable to state that semiotic method found application in areas such as law, cartoons, posters, theater, cinema, advertising, communications, linguistics, Turkish language and literature. In this regard, it is safe to say that semiotics is connected with many diverse disciplines.

However, it was thought that the lack of an analysis study related to the areas in which semiotic method was applied or studies in which semiotic method was used make it difficult for researchers 
Ercantürk, O. K. (2015). Trends in research in which written texts are analyzed in terms of semiotics: Content analysis of graduate thesis within the periods of 1985-2014. International Journal of Human Sciences, 12(2), 1309-1333. doi: $\underline{10.14687 / \text { ijhs.v12i2.3229 }}$

to carry out new studies. But, an analysis study on semiotics will provide guidance to researchers in order to conduct more qualified and comprehensive researches. Imposing no restrictions for future analysis study only within the field of semiotics will be able to provide in-depth information to researchers related to this field. Teachers and researchers, who intend to follow the developments in educational research, are aimed to be informed by the study prepared with these objectives (Çalık \& Sözbilir, 2014).

41 graduate thesis works, which analyze written texts through semiotic method and gained access from YOK National Thesis Center and the Central Library of Istanbul University, had been analyzed in this research that aims to present an analysis study. In this context, type and publication year of the graduate thesis works included within the scope of the research, universities, institutes and departments/disciplines in which these thesis works were conducted, their languages of publication, population and sampling in these thesis works, and type of written texts analyzed in them had been revealed.

It was seen when analyzing the distribution of graduate thesis works analyzed within the scope of the research according to their types that out of 41 graduate thesis works, 26 of them were master's theses and 15 of them were doctoral dissertations. According to this, it is possible to state that most of graduate thesis works that analyze written texts according to semiotic analysis method consisted of master's thesis works. There are also thesis works in other fields that analyze graduate thesis works. It was seen in these works that doctoral dissertations were less in number than master's thesis works. These can be exemplified as such: (Doğan \& Özçakmak, 2014; Elbir \& Yıldız, 2012; Girmen, Kaya, Bayrak, 2010; Göçen \& Okur, 2015; Kolaç, 2008; Yağmur Şahin, Kana \& Varışoğlu, 2013). This result is an expected outcome since producing a doctoral dissertation requires deeper studies and involves a longer process.

It was seen when looking at the acceptance dates of the graduate thesis works prepared with the aim of analyzing written texts through semiotic method within the scope of the research that they began in 1985. Graduate thesis works, conducted on the analysis of written texts in terms of semiotics, were seen to be produced every year in large proportions and number of these thesis works increased gradually up to the present. The recognition of semiotics and its association with other disciplines can be said to have a share in this. The increase was also seen in the number of thesis works conducted in different fields due to similar reasons. Gradual increase in the number of thesis works in Turkish education was also stated in the studies of Doğan \& Özçakmak (2014), and Yağmur Şahin, Kana \& Varışoğlu (2013). 
Ercantürk, O. K. (2015). Trends in research in which written texts are analyzed in terms of semiotics: Content analysis of graduate thesis within the periods of 1985-2014. International Journal of Human Sciences, 12(2), 1309-1333. doi: $\underline{10.14687 / \text { ijhs.v12i2.3229 }}$

18 different universities can be noticed when looking at the distribution of graduate thesis works that were included in the sampling and in which written texts were analyzed through semiotic method according to the universities they were prepared. This amount can be said to be inadequate when considering the number of universities in Turkey. While master's theses in the sampling were seen to be prepared in 16 different universities, doctoral dissertations were conducted in 6 different universities. It can be stated that the availability of experts on the field of semiotics who were employed at universities might have a share in this distribution. While Istanbul University was the university in which master's thesis works were conducted the most in terms of quantity within the scope of the research, doctoral dissertations were seen to be carried at Hacettepe University and Istanbul University the most in number. Hacettepe University was stated in the studies of Kolaç (2008) and Doğan \& Özçakmak (2014) to be one of the universities in which most number of thesis works were conducted at doctoral level on writing and listening skills in Turkish language teaching.

It was seen that out of 41 graduate thesis works, 39 of them were conducted at social sciences institute and 2 of them were at educational sciences institute. It is an expected result that execution of studies on semiotics at social sciences institute since semiotics is included in social sciences as a discipline. However, number of graduate thesis works, conducted at departments associated with educational sciences institute, was seen to be less even though data from semiotics was also used in the field of education. There is a more need for graduate works in which semiotics and education will be linked together and whose results will contribute to the field of education. In this sense, conducting graduate thesis works in the related field at departments affiliated with the institute of educational sciences will provide a significant contribution to education. Because, as stated by Batur (2010), semiotics addresses the elements of language, society and culture in a unified manner like mother tongue. Semiotics is seen as an area that can feed the native language with this aspect of it.

French Language and Literature department/discipline can be stated to be the department/discipline where most number of thesis works was conducted on the analysis of written texts in terms of semiotics when examining the distribution of graduate thesis works in the sampling according to the department/discipline. The multitude of these works can be said to contribute to the popularity of semiotics in Turkey. The most commonly used language in the preparation of graduate thesis works within the scope of the research was seen to be French with relation to the department/discipline. 
Ercantürk, O. K. (2015). Trends in research in which written texts are analyzed in terms of semiotics: Content analysis of graduate thesis within the periods of 1985-2014. International Journal of Human Sciences, 12(2), 1309-1333. doi: $\underline{10.14687 / \text { ijhs.v12i2.3229 }}$

It was noticed when examining the distribution of graduate thesis works, analyzed within the scope of the research, according to target population/ group that 48 different textbooks, works, authors or poets were selected as target population/group for analyzing the written texts in those thesis works. In this context, it was discovered when looking at the target population/group in graduate thesis works in the sampling that they mostly included authors of literary texts/works. In this sense, J. M. G. Le Clezio and Michel Tournier were the most preferred authors whose texts were selected for analysis. In addition to them, Ahmet Hamdi Tanpinar, Guy de Maupassant, Marcel Ayme, Murathan Mungan and Pertev Naili Boratav were also authors whose texts were chosen for analysis. Associating data from these works with Turkish education can be said to provide a significant contribution to teachers and students while selecting authors. In this sense, there is a need for the authors/poets that were suggested to students for reading in Turkish education to become subject of graduate thesis works.

A total of 211 texts/works were analyzed when looking at the texts/works studied in graduate thesis works within the scope of the research. In this regard, while texts/works of Ömer Seyfettin were analyzed the most, those of Murathan Mungan were the second and texts/works of Ahmet Hamdi Tanpinar were analyzed the third. It was seen when looking at the written texts analyzed in graduate thesis works within the scope of the research that only very few of them consisted of texts found in textbooks. A description was made in these thesis works by analyzing the texts in textbooks. However, text selection is an important issue in textbooks and there is a need for data from semiotics in this sense. In this regard, graduate thesis works, which reflect the necessary features of the texts to be included in textbooks and offer suggestion of texts for textbooks, can be considered to be essential.

Finally, what types of texts were included as written texts/works in the analyzed graduate thesis works in the sampling was considered within the scope of the research. According to this, texts in the form of stories were seen to be mostly chosen in thesis works for analysis. Novels were the second most chosen text type for analysis and fairy tales were the third most chosen text type. In this context, event-based text types were seen to be preferred for conducting analysis through semiotic method in graduate thesis works analyzed within the scope of the research. The reason behind this can be that the discovery of the text production process and obtaining a deeper understanding of the text are said to be quite easier in event-based texts. In addition to these, it was also noticed that only one sample each was analyzed from text types, such as epic, criticism and anecdotes, selected as sampling, but other text types, like legend and fable, were not included in the 
Ercantürk, O. K. (2015). Trends in research in which written texts are analyzed in terms of semiotics: Content analysis of graduate thesis within the periods of 1985-2014. International Journal of Human Sciences, 12(2), 1309-1333. doi: $\underline{10.14687 / \text { ijhs.v12i2.3229 }}$

studies included within the scope of the research. Need for studies on text types that were not studied previously or studied quite less in number can be stated according to this.

This study, which presented an analysis on graduate thesis works that analyze written texts through semiotic method, would be hoped to provide guidance for future studies in the field of semiotics and for different disciplines that make use of semiotic method. In this regard, the current status and inadequacies of the studies included in the sampling were attempted to be presented and suggestions related to the subject were offered. In addition to this, the following can be suggested for future studies:

- An analysis on graduate thesis works that analyze written texts through semiotic method was conducted in this study. Likewise, studies in other fields, such as painting, cinema and advertising, in which semiotic was used, can be conducted in a similar way.

- Studies of these types of analysis can also be carried out by analyzing articles in the field of semiotics.

\section{Bibliography}

Açan, A. Z. (2007). Türk İsaret Dili (TID)'deki temel tümce türlerinin el-dışı göstergeler açısından dilbilimsel incelenmesi. Doctoral Thesis, Hacettepe University, Institute of Social Sciences, Ankara. Obtained from https://tez.yok.gov.tr/UlusalTezMerkezi website.

Akdiş, M. (2013). Okul öncesi çocuklarm resimsel üretimlerinin göstergebilimsel açıdan çözü̈mlenmesi. Master's Course Thesis, Iş1k University, Institute of Social Sciences, Istanbul. Adopted from https://tez.yok.gov.tr/UlusalTezMerkezi .

Aslan Karakul, S. (2014). "Kapı”nın dili: Göstergebilimsel bir yaklaşım. Uluslararası Sosyal Arastirmalar Dergisi (The Journal of International Social Research), 7(35), 7-14.

Bakan, M. A. (2003). Marketing demographics, advertising semiotics: The case of Akssam newspaper. Master's Course Thesis, Middle Eastern Technical University, Institute of Social Sciences, Ankara. Obtained from https://tez.yok.gov.tr/UlusalTezMerkezi.

Barthes, R. (1979). Göstergebilim ilkeleri. (Trans. B. Vardar and M. Rifat). Ankara: Publications of the Ministry of Culture.

Barut, İ. (2010). Gülten Daynoğlu'nun çocuk romanlarnda dil tema ve eğitbilimsel göstergeler. Master's Course Thesis, Yüzüncü Y1l University, Institute of Social Sciences, Van. Acquired from https://tez.yok.gov.tr/UlusalTezMerkezi.

Başkan, Ö. (2003). Bildirişim insan-dili ve ötesi. Istanbul: Multilingual Publications.

Batur, Z. (2010). Ana dili öğretiminde göstergebilimin yeri: Ana dili ders kitaplarındaki sözel metinlerle görsel metinlerin bütünselliğinin analizi. Turkish Studies International Periodical For the Languages, Literature and History of Turkish or Turkic, 5(4), 174-200.

Bayav, D. (2006). Resimde göstergebilim, çocuk resimlerinin göstergebilimsel çözümlenmesi. Doctoral Thesis, Marmara University, Institute of Educational Sciences, Istanbul. Adopted from https://tez.yok.gov.tr/UlusalTezMerkezi. 
Ercantürk, O. K. (2015). Trends in research in which written texts are analyzed in terms of semiotics: Content analysis of graduate thesis within the periods of 1985-2014. International Journal of Human Sciences, 12(2), 1309-1333. doi: $10.14687 /$ ijhs.v12i2.3229

Bulut, 亡̇. (2009). Mehmet Hamdi Eyüboğlu yazmalarnm örneklenmesinin sanat eğitiminde (ilk.ögretim 6. ve 8. sinf düzeyinde) deneysel göstergeleri. Master's Course Thesis, Institute of Educational Sciences, Marmara University, İstanbul. Adopted from https://tez.yok.gov.tr/UlusalTezMerkezi.

Burunsuz, M. (2007). Semiyolojik açdan soyut resimde imge. Master's Course Thesis, Dokuz Eylül University, Institute of Educational Sciences, İmir). Adopted from https://tez.yok.gov.tr/UlusalTezMerkezi .

Buyurgan, T. (2013). Kişilerarası iletişim bağlamında aile ve çift ilişkilerinin göstergebilim bakıs açısıla çözümlenmesi: Mürekkep Bah̆̆g ve Balina. Master's Course Thesis, Marmara University, Institute of Social Sciences, İstanbul. Adopted from https://tez.yok.gov.tr/UlusalTezMerkezi.

Can, G. (2011). Göstergebilimsel açıdan Cibat Burak eserlerinin incelenmesi. Master's Course Thesis, Anadolu University, Güzel Sanatlar Enstitüsü, Eskişehir. Adopted from https://tez.yok.gov.tr/UlusalTezMerkezi .

Cohen, L., Manion, L. \& Morrison, K. (2007). Research methods in education. New York: Routledge.

Çalık, M. \& Sözbilir, M. (2014). İçerik analizinin parametreleri. Eğitim ve Bilim (Education and Science), 39(174), 33-38.

Çalık, M., Ünal, S., Çoştu, B. \& Karataş, F. Ö. (2008). Trends in Turkish science education. Essays in Education (Special edition), 23-45.

Çelebi, T. (2009). Reha Erdem sinemasina göstergebilim açısından bakeıs: Beş Vakit filminin göstergebilimsel bağlamda incelenmesi. Master's Course Thesis, Selçuk University, Institute of Social Sciences, Konya. Adopted from https://tez.yok.gov.tr/UlusalTezMerkezi.

Çetinkaya, B. (2006). Türkiye Türkçesinde mutluluk ve ü̃üntü göstergeleri. Doctoral Thesis, Gazi University, Institute of Social Sciences, Ankara. Adopted from https://tez.yok.gov.tr/UlusalTezMerkezi.

Çoşkun, E., Özçakmak, H. ve Balcı, A. (2012). Türkçe eğitiminde eğilimler: 1981-2010 y1lları arasında yapılan tezler üzerine bir meta-analiz çalışması. (Ed. E. Yılmaz, M. Gedizli, E. Özcan and Y. Koçmar), Türkçenin eğitimi ögretimi üzerine çalışmalar (Studies on Turkish Teaching) (p. 204-212). Ankara: Pegem Academy.

Çulha, O. (2011). Gösterge bilim (semiotics) tekniği kullanilarak Kanada fotoğraflarinin incelenmesi ZKU Journal of Social Sciences, 7(13), 409-424.

Deely, J. (1990). Basics of semiotics. Bloomington: Indiana University Press.

Demir, S. (2009). Göstergebilim, Umberto Eco ve yapıtlar bağlammnda göstergebilime katkuları. Master's Course Thesis, Istanbul University, Institute of Social Sciences, Istanbul. Adopted from https://tez.yok.gov.tr/UlusalTezMerkezi.

Denli, S. (1997). Göstergebilim açıından grafik gösterge anlamlarnın incelenmesi. Master's Course Thesis, Atatürk University, Institute of Social Sciences, Erzurum. Adopted from https://tez.yok.gov.tr/UlusalTezMerkezi.

Dervişcemaloğlu, B. (2005). Temel göstergebilim (semiyotik) kavramlar üzerine bir inceleme. Master's Course Thesis, Ege University, Institute of Social Sciences, İzmir. Adopted from https://tez.yok.gov.tr/UlusalTezMerkezi.

Deveci, M. (2010). Afiş Tasarmmnda göstergelerin kullanmmnn eğitimsel açıdan yeri ve önemi. Master's Course Thesis, Marmara University, Institute of Educational Sciences, İstanbul. Adopted from https:/ / tez.yok.gov.tr/UlusalTezMerkezi.

Doğan Topçu, A. (2005). Kayseri'yi okumak: Göstergebilimsel bir yaklaşımla bir şehrin analizi. Erciyes University Journal of the Institute of Social Sciences, 1(18), 237-246.

Doğan, Y. \& Özçakmak, H. (2014). Dinleme becerisinin eğitimi üzerine yapılan lisansüstü tezlerin değerlendirilmesi. Ana Dili Ë̆gitimi Dergisi (Mother Tangue Education), 2(2), 90-99. 
Ercantürk, O. K. (2015). Trends in research in which written texts are analyzed in terms of semiotics: Content analysis of graduate thesis within the periods of 1985-2014. International Journal of Human Sciences, 12(2), 1309-1333. doi: $10.14687 /$ ijhs.v12i2.3229

Elbir, B. \& Yıldız, H. (2012). İlköğretim yazma eğitimi üzerine yapılan lisansüstü çalışmalarının değerlendirilmesi. Akademik Bakıss (Academic Sight), 30, 1-11.

Er, N. (2007). İlköğretim Türkçe dersi ögretim programuyla kilavuz̨unun ve ögrrenci çalışma kitabımen (Türkşe 5) dilbilimsel açıdan değerlendirilmesi. Master's Course Thesis, Ankara University, Institute of Social Sciences, Ankara. Adopted from https://tez.yok.gov.tr/UlusalTezMerkezi.

Ercantürk, O. K. (2015). Göstergebilim açısından Türkģe ders kitaplar. Doctoral Thesis, Çanakkale Onsekiz Mart University, Institute of Educational Sciences, Çanakkale. Adopted from https://tez.yok.gov.tr/UlusalTezMerkezi.

Girmen, P., Kaya, F. \& Bayrak, E. (2010). Türkçe eğitimi alanında yaşanan sorunlanın lisansüstü tezlere dayalı olarak belirlenmesi. 9. Ulusal Simf Öğretmenlï̆i Ë̆itimi Semposyumu (National $9^{\text {th }}$ Symposium on Classroom Teaching) (20-22 May 2010), 133-138.

Göçen, G. \& Okur, A. (2015). Ortaokula yönelik söz varlığı araştırmalarının incelenmesi: Tezler. Ana Dili Ë̆itimi Dergisi (Mother Tangue Education), 3(1), 64-79.

Göçmen, P. (2006). Sanat eseri kullanulan reklamlarn göstergebilimsel açıdan incelenmesi. Master's Course Thesis, Gazi University, Institute of Educational Sciences, Ankara. Adopted from https://tez.yok.gov.tr/UlusalTezMerkezi.

Göktaş, Y., Hasançebi, F., Varışoğlu, B., Akçay, A., Bayrak, N., Baran, M. and Sözbilir, M. (2012). Türkiye'deki eğitim araştırmalarında eğilimler: Bir içerik analizi. Kuram ve Uygulamada Eğitim Bilimleri Dergisi (Educational Sciences: Theory \& Practice), 12, 177-199.

Göktaş, Y., Küçük, S., Aydemir, M., Telli, E., Arpacık, Ö., Yıldırım, G. \& Reisoğlu, İ. (2012). Educational technology research trends in turkey: a content analysis of the 2000-2009 decade. Educational Sciences: Theory \& Practice, 12(1), 191-196.

Guiraud, P. (1994). Göstergebilim (Trans. M. Yalçın). Ankara: İmge Publishing House.

Gün, M. (1990). Cağdaș anlatı ve kahplașmus anlatı gösterge bilimsel bir yaklaşım:Hayallerim, Așleım ve Sen. Master's Course Thesis, Gazi University, Institute of Social Sciences, Ankara. Adopted from https:// tez.yok.gov.tr/UlusalTezMerkezi.

Günay, V. D. (2012). Görsel göstergebilim - İmgenin anlamlandırılması. (Ed. D. Günay and A. Parsa). Görsel göstergebilim imgenin anlamlandirlması (p. 11-54). Istanbul: Es Publications.

Gür, N. (2013). Son yullarda yaymlanan televisyon reklamlarndaki dilin göstergebilim açısindan incelenmesi. Master's Course Thesis, Firat University, Elazığ.

Hanc1, H. (2008). Göstergebilimin grafik tasarm dersi alan ögrenciler üzerindeki etkisi. Master's Course Thesis, Gazi University, Institute of Educational Sciences, Ankara. Adopted from https://tez.yok.gov.tr/UlusalTezMerkezi.

İncekara, S. (2009). Uluslararsı alanda coğrafya eğitimi araştırmaları ve Türkiye'den örnekler: Mevcut durum ve gelecek yönler. Doğu Coğrafya Dergisi (Journal of Eastern Geography), 21, 123136.

İnceoğlu, Y. G. \& Çomak, N. A. (2009). Metin çöəü̈mlemeleri. Istanbul: Ayrıntı Publications.

Kalaman, S. \& Bat, M. (2014). Toplumsal cinsiyet açısından Axe basın ilanlanının göstergebilimsel açıdan analizi. KMU Sosyal ve Ekonomik Arastırmalar Dergisi (Journal of Social and Economic Researches), 16 (Özel Say1 I (Special Edition I) ), 128-136.

Karadağ, E. (2009). Eğitim bilimleri alanında yapılmış doktora tezlerinin incelenmesi Abi Euran University Ë̈itim Fakültesi Dergisi, 10(3), 75-87.

Kavuran, T. \& Acar, H. M. (2014). "Kayıp Balık Nemo”da masal işlevleri. Gar̨i University Iletetisim Kuram ve Arastirma Dergisi (Gari University Journal of Communication Theory and Practice), 39, 148158. 
Ercantürk, O. K. (2015). Trends in research in which written texts are analyzed in terms of semiotics: Content analysis of graduate thesis within the periods of 1985-2014. International Journal of Human Sciences, 12(2), 1309-1333. doi: $\underline{10.14687 / \text { ijhs.v12i2.3229 }}$

Kolaç, E. (2008). İlkokuma yazma alanında yapılan lisansüstü tezlerin değerlendirilmesi. VII. Ulusal

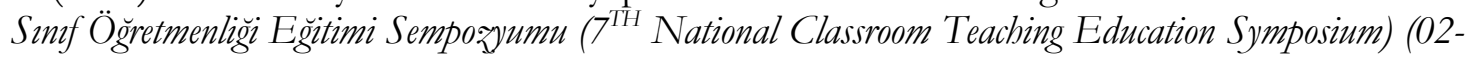
04 May), Canakkale. Adpted from http:/ $/$ www.google.com.tr/url?sa $=t \& r c t=j \& q=\& e s r c=s \&$ source $=$ web\&cd $=1 \& v e d=0 C C I$ QFjAA\&url $=$ http $\% 3 \mathrm{~A} \% 2 \mathrm{~F} \% 2 \mathrm{Fturkoloji.cu.edu.tr} \% 2 \mathrm{FYENI} \% 2520 \mathrm{TURK} \% 2520 \mathrm{DILI} \% 2$ Femine kolac lisansustu calismalar.pdf\&ei=VDruVPWqN4atU5OlgagE\&usg=AFQjCN EEud9BzHxmaMMgrO0ujcFPdjocEA\&sig2=uayPnaiOO weQVXasH8O5Q\&bvm=bv.8 $\underline{6956481, \mathrm{~d} \cdot \mathrm{d} 24 \& \mathrm{cad}=\mathrm{rja}}$

Koz, K. A. (2007). Siyasal karikatürlerde lider imajl: 1987 genel seçimleri bağlammnda parti liderlerinin Türk. basınnda karikatürize edilisis. Master's Course Thesis, Gazi University, Institute of Social Sciences, Ankara. Adopted from https://tez.yok.gov.tr/UlusalTezMerkezi.

Kuleli, M. \& Ural, G. (2015). Gösterge çözüm yöntemi ile William Shakespeare'in "Merchant Of Venice" eserinde mitolojik ve ikonografik göndergelerin saptanması ve Türkçe çevirilerinin değerlendirilmesi. Dil ve Edebiyat Eğitimi Dergisi (Journal of Language and Literature Education), $13,1-24$.

Ormanlı, O. (2014). Sinemada edebiyat uyarlamaları ve göstergeler: Muhteşem Gatsby (2013) filmi örneği. The Turkish Online Journal of Design, Art and Communication - TOJD AC, 2, 85-91.

Özcan, E. (2007). Göstergebilimsel açıdan reklam dilinin tüketim toplumuna etkileri. Master's Course Thesis, Süleyman Demirel University, Institute of Social Sciences, Isparta. Adopted from https://tez.yok.gov.tr/UlusalTezMerkezi.

Özçelik, E. (2007). Türkiye'de çocuk yaz̨n ürünlerinde eğitbilimsel göstergeler. Master's Course Thesis, On Dokuz Mayis University, Institute of Social Sciences, Samsun. Adopted from https://tez.yok.gov.tr/UlusalTezMerkezi.

Özdemir, M. D. (2010). Ziya Gökealp'in şïrlerinde dil, milli kültür ve aidiyet kavramlarnnn göstergebilim açusindan incelenmesi. Master's Course Thesis, Hacettepe University, Institute of Social Sciences, Ankara. Adopted from https://tez.yok.gov.tr/UlusalTezMerkezi.

Özmutlu, A. (2009). Grafike tasarm atölye derslerinde afis konusunun uygulama ve çözümleme süreglerinde göstergebilimsel çözümleme yönteminin kullanmı. Master's Course Thesis, Samsun Ondokuz Mayis University, Institute of Social Sciences, Samsun. Adopted from https://tez.yok.gov.tr/UlusalTezMerkezi.

Parsa, S. \& Parsa, A. (2012). Göstergebilim çözüumlemeleri. İzmir: Ege University Publishing House.

Rifat, M. (1996). Göstergebilimcinin kitabı. İstanbul: Düzlem Publications.

Rifat, M. (1999). Gösterge elestirisi. İstanbul: Kaf Publication.

Rifat, M. (2011). Homo semioticus ve genel göstergebilim sorunlar. İstanbul: Yap1 Kredi Publications.

Sabanc1, E. (2014). Balkan Naci İslimyeli'nin eserlerinin göstergebilimsel analiz̨i. Master's Course Thesis, Gazi University, Institute of Educational Sciences, Ankara. Adopted from https://tez.yok.gov.tr/UlusalTezMerkezi.

Sayar, E. (2013). Orhan Veli'nin “İstanbul'u Dinliyorum” şiiri üzerinden İstanbul'u göstergebilimsel okumak. TurkishStudies - International Periodical For The Languages, Literature and History of Turkish or Turkic, 8(9), 2185-2200.

Selçuk, Z., Palanc1, M., Kandemir, M. \& Dündar, H. (2014). Eğitim ve Bilim dergisinde yayınlanan araştırmaların eğilimleri: İçerik analizi. Ë̆itim ve Bilim (Education and Science), 39(173), 430-453.

Sözbilir, M. \& Kutu, H. (2008). Development and current status of science education research in Turkey. Essays in Education [Special issue], 1-22. 
Ercantürk, O. K. (2015). Trends in research in which written texts are analyzed in terms of semiotics: Content analysis of graduate thesis within the periods of 1985-2014. International Journal of Human Sciences, 12(2), 1309-1333. doi: 10.14687/ijhs.v12i2.3229

Şahin, İ. (2000b). Kentsel biçimbilim çözümlemesinde göstergebilimsel yaklaşım: "Kayaköy" örneğinde irdeleme Master's Course Thesis, Mimar Sinan University, Institute of Science, İstanbul. Adopted from https://tez.yok.gov.tr/UlusalTezMerkezi.

Şahin, S. (2000a). Eine vergleichende studie über die semiotische bedeutung der karikaturen in Deutschen und Türkischen zeitungen/Alman ve Türk gazatelerindeki karikatürlerin göstergebilim acısından karşılaştırması üzerine bir çalıșma. Master's Course Thesis, Hacettepe University, Institute of Social Sciences, Ankara. Adopted from https://tez.yok.gov.tr/UlusalTezMerkezi.

Şimşek, A., Özdamar, N., Becit, G., Kılıçer, K., Akbulut, Y. \& Yıldırım, Y. (2008). Türkiye’deki eğitim teknolojisi araştırmalarında güncel eğilimler. Selcuk University Journal of Social Sciences, 19, 439-458.

Şimşek, A., Özdamar, N., Kobak, K., Uysal, Ö., Berk, C., Kılıçer, T. \& Çiğdem, H. (2009). İkibinli yıllarda Türkiye'deki eğitim teknolojisi araşturmalarında gözlenen eğilimler. Kuram ve Uygulamada Eğitim Bilimleri (Educational Sciences: Theory \& Practice), 9, 115-120.

Tekin, A. (1996). Göstergebilim ve sinema, temel kavramlar retorik göstergebilimsel çözüumleme yöntemi model önerisi ve bir örnek çözümleme 2001: A Space Odyssey. Doctoral Thesis, Marmara University, Institute of Social Sciences, İstanbul. Adopted from https://tez.yok.gov.tr/UlusalTezMerkezi.

Tomak, A. (1997). Şïr ve öykü kitaplarnnda kapak tasarmlarnm göstergebilimsel analiz̨ ve öneriler. Master's Course Thesis, Ondokuz Mayis University, Institute of Social Sciences, Samsun. Adopted from https://tez.yok.gov.tr/UlusalTezMerkezi.

Türkcan, B. (2013). Çocuk resimlerinin analizinde göstergebilimsel bir yaklaşım. Kuram ve Uygulamada Ë̈itim Bilimleri (Educational Sciences: Theory \& Practice), 13(1), 585-607.

Türkcan, B. \& Girmen, P. (2012). İlköğretim öğrencilerinin şïr ve resimlerinin göstergebilimsel analizi. Elektronik Sosyal Bilimler Dergisi (Electronic Journal of Social Sciences), 11(42), 241-263.

Ulutaş, F. \& Ubuz, B. (2008). Matematik eğitiminde araştırmalar ve eğilimler: 2000 ile 2006 ylları aras1. İlkögretim Online, 7(3), 614-626.

Uzun, E. (2006). Hukukun göstergebilimsel analiz̧i. Doctoral Thesis, Anadolu University, Institute of Social Sciences, Eskişehir. Adopted from https://tez.yok.gov.tr/UlusalTezMerkezi.

Vardar, B. (2001). Dilbilimin temel kavram ve ilkeleri. İstanbul: Multilingual Publications.

Varışoğlu, B., Şahin, A. and Göktaş, Y. (2013). Türkçe Eğitimi araştırmalarında eğilimler. Kuram ve Uygulamada Eğitim Bilimleri (Educational Sciences: Theory \& Practice), 13(3), 1767-1781.

Vicdan, M. (2010). Türk Dili ve Edebiyatı ögretim programlarnnda dilbilim ve göstergebilim kuramlarmm etkileri. Master's Course Thesis, Afyon Kocatepe University, Institute of Social Sciences, Afyonkarahisar. Adopted from https://tez.yok.gov.tr/UlusalTezMerkezi.

Yağmur Şahin, E., Kana, F. \& Varışoğlu, B. (2013). Türkçe eğitimi bölümlerinde yapılan lisansüstü tezlerin araştırma eğilimleri. International Journal of Human Sciences, 10(2), 356-378.

Yavuz, M. (2001). Metinlerde edimsel gösterge çözümlemesinin eğitim amaçl kullanımı. Master's Course Thesis, İstanbul University, Institute of Social Sciences, İstanbul. Adopted from https://tez.yok.gov.tr/UlusalTezMerkezi .

Yıldız, P. (2005). Sahne ve seyirci etkileşiminin tarihsel gelişiminde göstergebilimsel açıdan bir analiz. Selçuk University Journal of Institute of Social Sciences, 13, 425-442.

Yilmaz, E. (2002). Heykel sanatına göstergebilimsel bir yaklaşım. Master's Course Thesis, Anadolu University, Institute of Social Sciences, Eskişehir. Adopted from https://tez.yok.gov.tr/UlusalTezMerkezi . 